\title{
ROAD AND BRIDGE CONSTRUCTION ACROSS GYPSUM KARST IN ENGLAND
}

Anthony H. Cooper, British Geological Survey, Keyworth, Nottingham, NG12 5GG, UK. Jonathan M. Saunders, Joynes Pike \& Associates Ltd, 7 South Parade, Doncaster DN1 2DY, UK.

Presented at the $7^{\text {th }}$ Multidisciplinary Conference on Sinkholes and the Engineering and Environmental Impacts of Karst Harrisburg-Hershey/Pennsylvania 1999.

Published in Engineering Geology 2002 Vol. 65 217-223

Manuscript copyright of the authors and their respective institutions.

Please respect copyright. For private study only

\begin{abstract}
Gypsum karst problems in the Permian and Triassic sequences of England have caused difficult conditions for bridge and road construction. In Northern England, the Ripon Bypass crosses Permian strata affected by active gypsum karst and severe subsidence problems. Here, the initial borehole site investigation for the road was supplemented by resistivity tomography studies. The roadway was reinforced with two layers of tensile membrane material within the earth embankment. This will prevent dangerous catastrophic collapse, but will allow sagging to show where problems exist. The River Ure Bridge was constructed across an area of subsidence pipes filled with alluvial deposits. It was built with extra strength, larger than normal foundations. If one pier fails the bridge is designed for adjacent arches to span the gap without collapse. The bridge piers are also fitted with electronic load monitoring to warn of failure. In the Midlands area of England, road construction over Triassic gypsum has required a phase of ground improvement on the Derby Southern Bypass. Here, the gypsum caps a hill where it was formerly mined; it dips through a karstic dissolution zone into an area of complete dissolution and collapse. The road and an associated flyover were built across these ground conditions. A major grouting program before the earthworks began treated the cavities in the mine workings and the cavernous margin of the gypsum mass. Within the karstic dissolution zone gypsum blocks and cavities along the route were identified by conductivity and resistivity geophysical surveys, excavated and backfilled. In the areas of complete dissolution and collapse the road foundation was strengthened with vibrated stone columns and a reinforced concrete road deck was used.
\end{abstract}

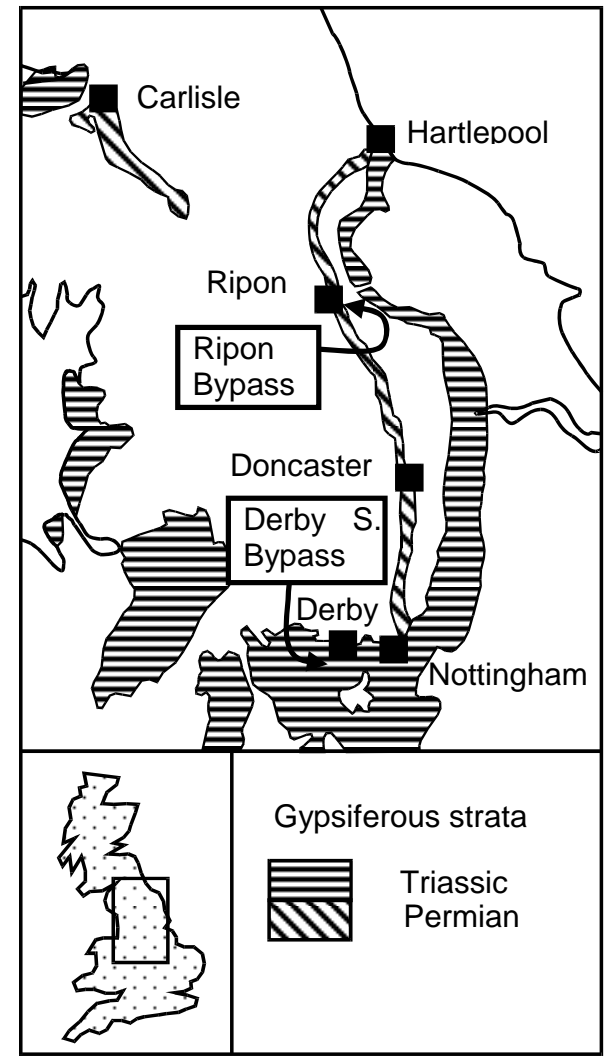

\section{INTRODUCTION}

Gypsum $\left(\mathrm{CaSO}_{4} .2 \mathrm{H}_{2} \mathrm{O}\right)$ is readily soluble in water and develops karst features much more quickly than does limestone. Road construction over gypsiferous terranes has to deal with karst problems including progressive dissolution, sinkhole formation and poor ground conditions caused by collapsed strata. Furthermore, the complete dissolution of gypsiferous beds can leave a residue of weak and brecciated strata which also produces difficult conditions for construction. Where gypsum is present in the bedrock, either as massive beds or as veins, it can be associated with sulphate-rich groundwater that can be harmful to concrete, and precautions to prevent damage should be considered (Forster et al., 1995).

The Permian and Triassic strata in England both contain thick gypsum sequences, but individually their associated rocks and respective engineering problems are different. The most problematical gypsum karst conditions are found in the Permian rocks, notably in the Ripon area of North Yorkshire. Gypsum karst and difficult ground conditions have been encountered in the Triassic rocks of the English Midlands in the area to the south-west of Derby. These are described below with details of the difficulties encountered during road construction and their engineering solutions.

\section{RIPON BYPASS \\ Geology and gypsum karst problems}

The Ripon Bypass was constructed to the east of Ripon. It crosses the Permian sequence which includes approximately $35 \mathrm{~m}$ of gypsum in the Edlington Formation (formerly the Middle Marl) and 10m of gypsum in the higher Roxby Formation (formerly

Figure 1. The distribution of the Permian and Triassic gypsiferous sequences in the United Kingdom and locations of the Ripon Bypass and the Derby Southern Bypass. 
the Upper Marl). These two gypsum sequences rest on two limestone aquifers, the Cadeby Formation (formerly the Lower Magnesian Limestone) and the Brotherton Formation (formerly the Upper Magnesian Limestone) respectively. The limestone dip slopes act as catchment areas and the underground water flows down-dip into the gypsiferous sequences, before escaping into a major buried valley along the line of the Rive Ure (Cooper, 1986, 1995, 1998). Complex cave systems have developed in the gypsum, and artesian, sulphaterich springs are locally present. Because of the thickness of gypsum the caves are large and surface collapses up to $30 \mathrm{~m}$ across and $20 \mathrm{~m}$ deep have been recorded. The subsidence is not random, but occurs in a reticulate pattern related to the jointing in the underlying strata (Cooper, 1986). However, it is impossible to predict where the next subsidence event will occur. Around Ripon, a significant subsidence occurs approximately every year (Cooper, 1995). The dates of the subsidence events show that some areas are more active than others, especially areas bounding the Ure valley where cave water escapes into the buried valley gravels. The new Ripon Bypass crosses the subsidence belt and the new Ure Bridge is situated in a very active area. The new road and bridge pass close to several subsidence hollows.

\section{Engineering solutions}

In addition to the standard site investigation that was undertaken for the Ripon Bypass, a desk study of the subsidence features was carried out. This study included an assessment of the likely magnitude and frequency of the subsidence events along the route of the road. Resistivity tomography was also undertaken on the bridge site, but the results were inconclusive and no additional subsidence features were pinpointed. Even if a costly investigation of closely spaced boreholes had been undertaken, it is unlikely that any cavities or breccia pipes which were identified could be stabilised. Grouting was impractical due to the large size of the cavities and the fact that filling them was likely to cause accelerated dissolution in the adjacent ground. Because the line of the bridge could not be changed a decision was made to design and construct the bridge with inbuilt protection against future ground subsidence.

A conventional bridge in a non-hazardous area would comprise piers with individual sections of road deck (Figure 2A). The new Ripon Bridge has a strengthened heavy-duty steel girder construction designed with sacrificial supporting piers. The structure will withstand the loss of any one support pier without collapsing (Figure 2B), (Thomson et al., 1996). The individual piers have larger than normal foundation pads, in order to span a small subsidence event. On the alluvial deposits of the river flood plain the ground was improved by the use of stone columns. Piling was also undertaken for one of the piers. In addition to the bridge strengthening, the piers are equipped with electronic monitoring devices to detect separation from the deck. The philosophy of the approach has been to maintain public safety, while not over-engineering the structure to an excessive degree with the resultant heavy financial costs. In addition to these measures, an added degree of security could have been obtained by extending the foundations of each pier laterally to an extent that could span the normal-sized collapses (Figure 2C).

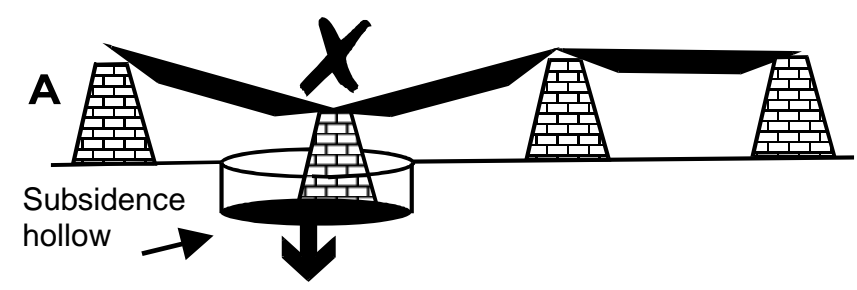

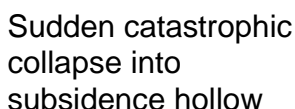

subsidence hollow
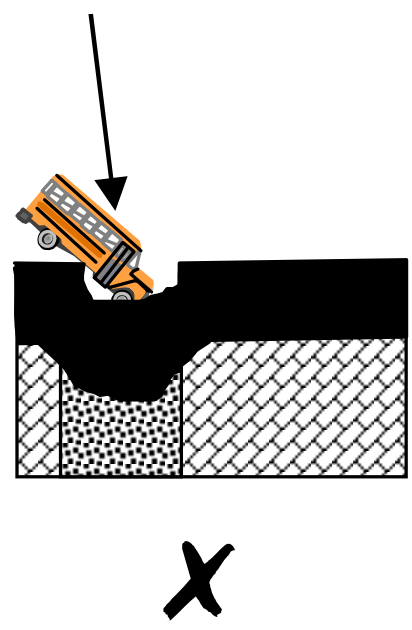

Layers of high-tensile reinforced plastic grid material in road sub-base and embankments to protect against sudden collapse

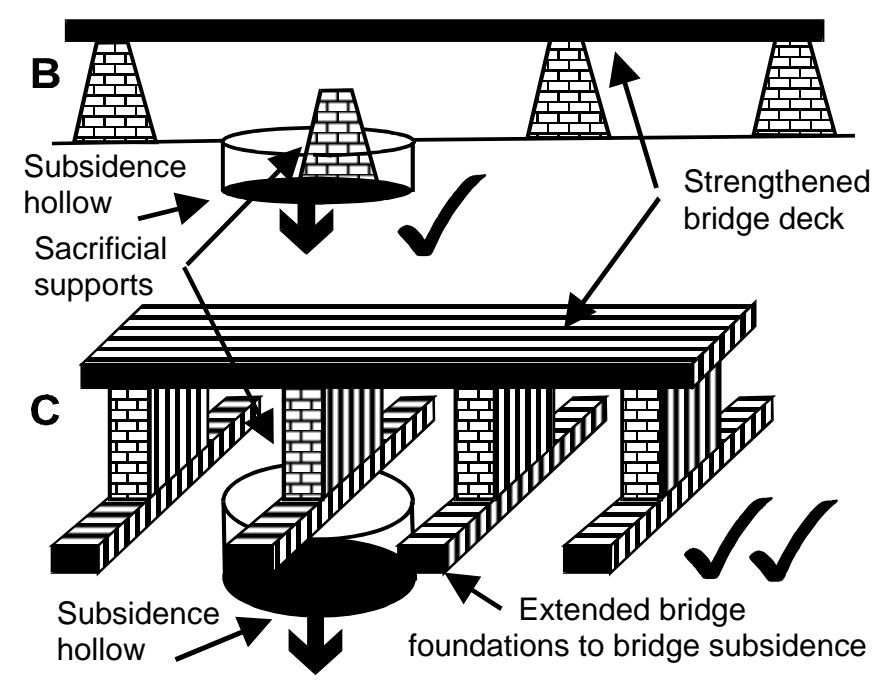

Figure 2. Sacrificial supports and extended foundations in bridge construction to protect against sudden subsidence failure.
Figure 3. The use of tension membrane material or "Geogrid" in road construction to protect against subsidence failure and sudden collapse. 
Regarding the construction of the road, the priority was again the maintenance of public safety without the unacceptable cost of investigating possible subsidence features that would be difficult or impossible to remediate. The course of the road could not be changed as it follows a disused railway line. The solution was to use tension membranes with a design brief that the integrity of the road should be supported for at least a 24-hour period following ground subsidence (Kempton, et al., 1996). This would allow time for any problem to be identified and isolated from the public. The tension membrane material, or geogrid, used was ParaLink 700S and $325 \mathrm{~S}$ incorporated in the road embankment (Kempton, et al., 1996: Thomson et al., 1996). The embankment/membrane combination was modelled using a FLAC (Fast Lagrangian Analysis of Continua) computer programme to simulate the occurrence of a typically sized collapse void beneath the road (Kempton, et al., 1996). The incorporation of these membranes in the road will allow the road to sag into any subsidence void beneath it, thus showing there is a problem, but catastrophic collapse should not occur (Figure 3). The use of geotextile materials in this way is a proven method of protecting public safety in car parks and public spaces.

\section{DERBY SOUTHERN BYPASS}

Geology and gypsum karst problems

The Derby Southern Bypass is a 24km long strategic link road between the M1, near Derby, to the M6 at Stafford. It includes 72 major engineered structures, and the design and supervision of the construction works was carried out by Scott Wilson on behalf of the Highways Agency. The road crosses the Triassic Mercia Mudstone Group of rocks (formerly called the Keuper Marl), that are mainly sandstones and calcareous or dolomitic mudstones, with two main sequences of gypsum in the upper part of the group. These are the Tutbury and Newark gypsum beds of the Cropwell Bishop Formation (Elliot 1961; Charsley et al. 1990).

The Mercia Mudstone Group has a reputation for having complex weathering and requiring careful site investigation (Chandler, 1969; Bacciarelli, 1993). In some places, the rock has a low bearing capacity and a complex weathering profile with less weathered rock commonly overlying severely weathered material. In some parts of the sequence this can be attributed to differently cemented strata. Elsewhere, this weathering may be attributed to the dissolution of gypsum in the near-surface strata, possibly to a depth of $30 \mathrm{~m}$ (Elliot, 1961; Reeves, et al., 1993). In these areas, caution has to be exercised as engineering works, such as piling, may open channels for water ingress into the gypsiferous strata. If this happens, and there is a throughput of water, gypsum dissolution may occur similar to that recorded at Ratcliffe-on-Soar Power Station, near Nottingham (Seedhouse and Sanders, 1993).

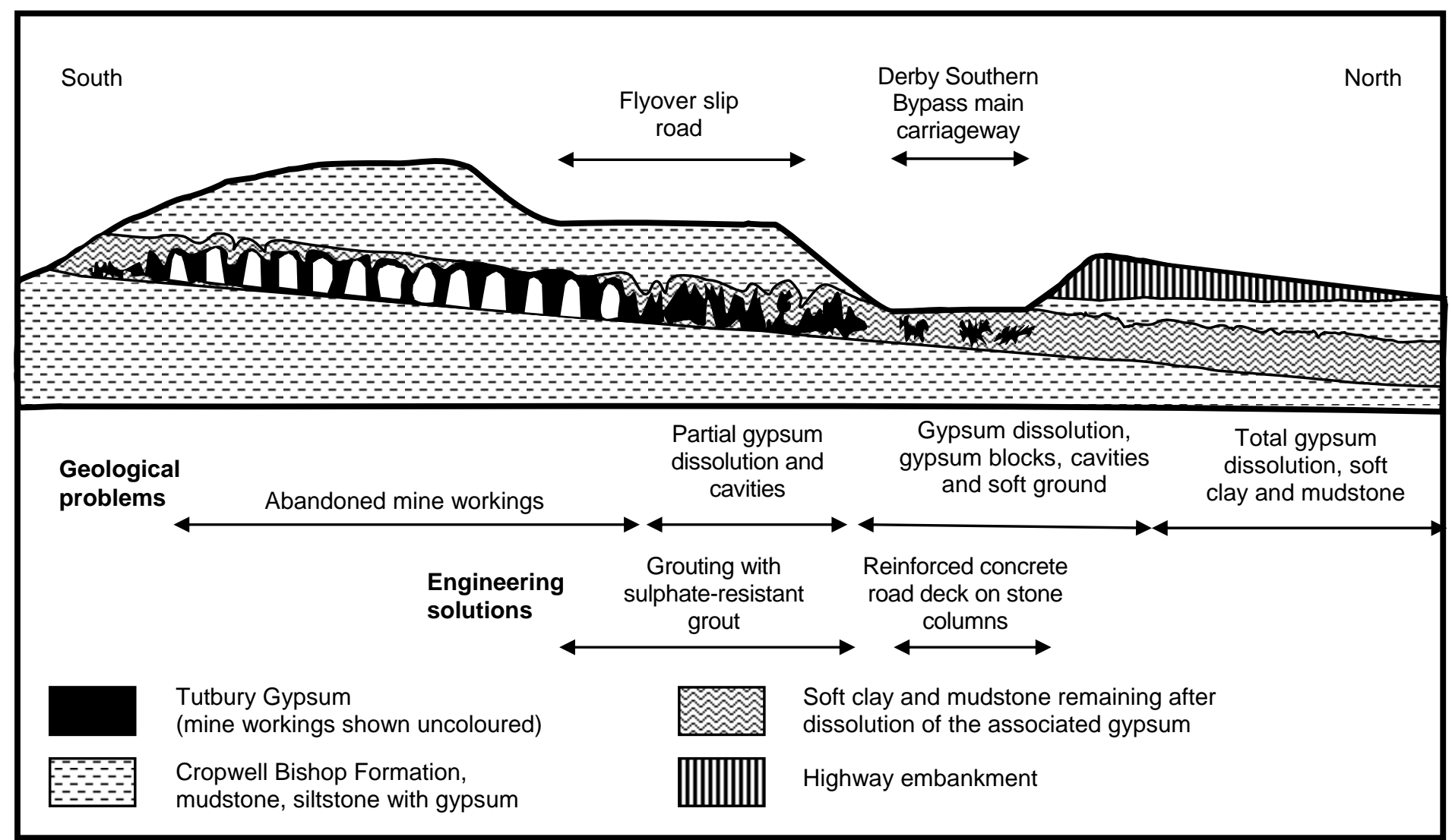

Figure 4. Stylised cross-section (not to scale) through the Tutbury Gypsum, mine workings and gypsum dissolution zone at Aston Hill south-west of Derby on the Derby Southern Bypass.

The Tutbury gypsum is best developed in the area south and southwest of Derby where it reaches about $10 \mathrm{~m}$ in thickness. The overlying Newark gypsum here comprises mainly thin beds and veins. The thick Tutbury gypsum bed has a long history of mining and quarrying dating back to the Middle Ages. Initially it was worked for monumental alabaster and in 1367 Edward III had blocks of 
Chellaston alabaster taken to the Chapel of the Garter at Windsor Castle. From the $19^{\text {th }}$ Century onwards it was increasingly exploited for plaster manufacture (Smith, 1918; Sherlock \& Hollingworth, 1938). There are still several working gypsum mines extracting the Tutbury seam in the region, but not locally. The Tutbury gypsum is not well documented, but the descriptions of Smith (1918) record much of it as massive and nodular. Features that we now consider to be of karst origin are also described including dissolution features and areas of collapse. In the gypsum mines at Fauld, about 20km to the south-west of the construction site, Wynne (1906) described caves and collapse features similar to those seen in the Permian gypsum of the Vale of Eden (Ryder and Cooper, 1993).

The construction of the Derby Southern Bypass, near Aston-on-Trent, took the main east-west carriageway along the base of Aston Hill with an interchange linking it to the A6 Derby Spur road. The associated slip roads for the spur passed through a deep cutting in the northern flank of the hill. Available published geological maps (British Geological Survey, 1976: now resurveyed) and unpublished documents were consulted during the initial desk study and subsequent design stages. They indicated that the workings of the Aston Holme Gypsum Mine beneath the hill would underlie the slip roads. They also suggested that the gypsum dipped about 3 degrees to the north and would crop out on the side of the hill in the middle of the cutting. The detailed ground investigations showed the mainline of the road to be underlain by up to $8 \mathrm{~m}$ of soft to very soft clays and silts. These belonged to the Mercia Mudstone Group, had low bearing capacities and a long-term settlement potential. The ground investigation showed the gypsum workings beneath Aston Hill to be above the groundwater table. For safety reasons, it was decided that the mine workings should be treated by a phase of drilling and grouting prior to the excavation of the cutting. This was because of the potential for significant voids to be encountered at various levels during the earthworks, a factor that would pose a risk to personnel and heavy construction traffic.

During the drilling and grouting programme, it became apparent that the Tutbury seam was in fact present at a greater depth than indicated by the published geological records. However, the final rockhead cover was insufficient to negate any long-term risk of void migration. In addition, during the initial earthworks for the main carriageways three minor collapses were encountered. These three areas were investigated by a grid of 12 drill-holes to depths of between $15 \mathrm{~m}$ and $30 \mathrm{~m}$. No gypsum was encountered and grout takes were minimal. It was concluded that the gypsum seam was present at a depth greater than originally envisaged and that it passed beneath the mainline of the road (Figure 4). It was concluded that the gypsum mine workings were not restricted by the seam outcrop, on the side of Aston Hill, but by a zone of dissolution at the edge of the mine. Down dip from the mine, the gypsum passes into a zone of partial dissolution and collapsed strata. This comprises a mixture of large, partially dissolved gypsum blocks up to $4 \mathrm{~m}$ in diameter, collapsed areas and some natural cavities. Further down dip, beneath the River Trent floodplain the gypsum has been totally dissolved resulting in a sequence of insoluble residue and collapsed confining strata. The sequence formerly associated with the gypsum is present as a mixture of soft to very soft clay with brecciated mudstone clasts. Deep boreholes showed that farther down dip, where there was little groundwater circulation, the gypsum had not been dissolved and was again present. Some of the subsidence hollows encountered during the excavations contained glacial and periglacial deposits. It is probable that the karst mechanisms that dissolved the gypsum may be related to past fluctuations in the groundwater levels. These fluctuations might relate to decreasing water table levels associated with post-glacial river incision and a change in base level. This is suggested by the presence of extensive stepped terraces along the valley here.

\section{Engineering solutions}

The area of mine workings and partial dissolution beneath the slip road area was treated by a phase of drilling and grouting. At the start, a perimeter grout curtain was formed by grouting holes initially at $3 \mathrm{~m}$ centres, reduced to $1.5 \mathrm{~m}$ centres in areas of significant grout take. The enclosed area was then grouted on an initial $6 \mathrm{~m}$ grid with secondary grouting at $3 \mathrm{~m}$ centres in areas of significant grout take. Tertiary grouting was undertaken at $1.5 \mathrm{~m}$ centres for areas of significant grout take during the secondary phase. The boreholes were drilled by open-hole percussive techniques and air flush. Grouting was achieved by the installation into the boreholes of a tube, nominally $50 \mathrm{~mm}$ in diameter, with an inflatable packer. Grout was injected at a maximum pressure of $965 \mathrm{kPa}(140 \mathrm{psi})$. Approximately 2900 holes were drilled to a maximum depth of $32 \mathrm{~m}$ and an average depth of $20 \mathrm{~m}$. The maximum void height encountered was $7.5 \mathrm{~m}$ with several migrating voids encountered at depths as shallow as $2 \mathrm{~m}$ below original ground level.

The mainline carriageway and approach roads to the A6 Derby Spur Bridge were in an area of complete gypsum dissolution and soft strata. Here, the foundation strata were improved by the installation of $450 \mathrm{~mm}$ diameter stone columns on a grid to a typical depth of $10 \mathrm{~m}$. In addition, sections of the mainline carriageway were constructed using a continuously reinforced concrete carriageway to span any minor localised shallow subsidence.

Because the Tutbury gypsum seam was found beneath all the slip roads and the mainline of the road, it was deemed prudent to carry out a two-phase geophysical survey to look for possible cavities and soft ground. The geophysics comprised ground conductivity and ground resisitivity techniques undertaken over approximately $900 \mathrm{~m}$ of highway route. The survey identified two areas where anomalies were encountered at depths of between $6 \mathrm{~m}$ to $8 \mathrm{~m}$ below finished road level. These were correlated to possible voids and water-filled ground, or zones of very soft clay. The anomalies affected a total length of $75 \mathrm{~m}$ of highway and these areas were treated by the installation of stone columns.

\section{DISCUSSION}

The construction of bridges and viaducts over actively dissolving gypsum karst is difficult. Unlike the relatively slow formation of limestone karst, gypsum karst can develop on a human/engineering time-scale. Furthermore, the site investigation of cavernous ground is difficult, especially where thick Quaternary deposits overlie gypsum that is dissolving to depths of $80 \mathrm{~m}$ or more. Many of the engineering solutions used in limestone karst areas are not appropriate. Grouting is commonly used to fill cavities and stabilise the ground in limestone karst, but in gypsum karst it can only be used in areas like the Derby Southern Bypass where there is very little groundwater movement. Where there is high groundwater movement, such as at Ripon, the high dissolution rate of gypsum, the 
aggressive nature of sulphate-rich water, the cavity sizes and the difficulties of actually sealing them make grouting impractical. Incomplete grouting may actually aggravate the situation by causing enhanced dissolution in the adjacent ground around the treated area. Because grouting is largely ineffective it can be argued that in many areas exhaustive site investigation to find the cavities is not cost-effective, unless the road can be re-routed to avoid them. The alternative approach is to look for the obvious problems, such as known sinkholes, avoid them and build strength and safety measures into the structures; this is the approach that was taken by the road engineers at Ripon. A similar approach has been taken by French engineers for road construction around Paris. Some of the gypsum karst has been grouted (Cadilhac et al., 1997; Poupelloz \& Toulemont, 1981), but additional safety measures have also been used. Viaducts around Paris have been constructed with foundations that will span the likely size of collapse (Arnould, 1970). In addition, benchmarks to monitor movement have been installed and these are surveyed regularly. A network of inclinometers and extensometers are automatically monitored and linked to a warning system that is activated if the settlement exceeds $60 \mathrm{~mm}$. During the viaduct construction all known cavities were filled, but the structures were also designed with grout-holes for future possible use to enable new cavities to be grouted (Arnould, 1970). The similar use of extended foundation designs and strengthened structures has similarly been used in Germany and Russia (Reuter and Tolmačëv, 1990; Sorochan, et al., 1985).

The complete dissolution of gypsum also leads to problems where construction has to deal with the residual deposits caused by gypsum removal and collapse. In the UK, where this process has occurred in the Mercia Mudstone Group it has commonly produced ground with a low bearing capacity. The distinctive weathered character of the Mercia Mudstone has been known for some time (Chandler, 1969; Bacciarelli, 1993). However, very little attention has been paid to the presence of gypsum in the unweathered rock, its removal by dissolution and the resultant deposits. The excavations on the Derby Southern Bypass show the effects of dissolution removing thick gypsum deposits and the resultant soft, collapsed ground. Gypsum is not uniformly distributed throughout the Mercia Mudstone Group and it is likely that there is some correlation between the areas with the lowest bearing capacity, the stratigraphy and the former presence of gypsum.

\section{ACKNOWLEDGEMENTS}

The Highways Agency and Scott Wilson are thanked for permission to publish construction details of the Derby Southern Bypass. Tim Charsley, Alan Forster and Dave Entwhistle are thanked for reviewing the manuscript. AHC publishes with permission of the Director, British Geological Survey (N.E.R.C.).

\section{REFERENCES}

Arnould, M. 1970. Problems associated with underground cavities in the Paris region. 1-25 in Geological and geographical problems of areas of high population density. Proceedings of the symposium, Association of Engineering Geologist, Sacramento, California.

Bacciarelli, R. 1993. A revised weathering classification for Mercia Mudstone (Keuper Marl) 169-174 in Cripps, J.C., Coulthard, J.C., Culshaw, M.G., Forster, A., Hencher, S.R. and Moon, C. (Editors). The Engineering Geology of Weak Rock. Proceedings of the 26th annual conference of the Engineering Group of the Geological Society, Leeds, September, 1990. A.A.Balkema, Rotterdam.

British Geological Survey, 1976. Loughborough, Sheet 141, Solid and Drift. 1:50 000 (Southampton: Ordnance Survey for the British Geological Survey).

Cadilhac, M., Poupelloz, B. \& Toulemont, M. 1977. Fondations d'ouvrage d'art en site karstique. Le viaduc de l'autoroute A15. Bulletin de Liaison Labo. P. et Ch. 87. janv.-févr. Réf. 1915.

Chandler, R.J. 1969. The effects of weathering on the shear strength properties of Keuper Marl. Geotechnique, Vol. 19, 321-334.

Charsley, T.J, Rathbone, P.A. and Lowe, D.J. 1990. Nottingham: A geological background for planning and development. British Geological Survey Technical Report WA/90/1.

Cooper, A H. 1986. Foundered strata and subsidence resulting from the dissolution of Permian gypsum in the Ripon and Bedale areas, North Yorkshire. 127-139 in Harwood, G M and Smith, D B (eds). The English Zechstein and related topics. Geological Society of London, Special Publication. No. 22.

Cooper, A.H. 1995. Subsidence hazards due to the dissolution of Permian gypsum in England: investigation and remediation. 23-29 in Beck, F.B. (ed.) Karst Geohazards: engineering and environmental problems in karst terrane. Proceedings of the fifth multidisciplinary conference on sinkholes and the engineering and environmental impacts of karst Gatlinburg/Tennessee/2-5 April 1995. 581pp. A.A.Balkema, Rotterdam.

Cooper, A.H. 1996. Gypsum: geology, quarrying, mining and geological hazards in the Chellaston area of South Derbyshire. British Geological Survey Technical Report WA/96/30 
Cooper, A.H. 1998. Subsidence hazards caused by the dissolution of Permian gypsum in England: geology, investigation and remediation. In Maund, J.G. \& Eddleston, M (eds.) Geohazards in Engineering Geology. Geological Society, London, Engineering Special Publications, 15, 265-275.

Elliot, R.E. 1961. The stratigraphy of the Keuper Series in Southern Nottinghamshire. Proceedings of the Yorkshire Geological Society. Vol. 33. 197-234.

Forster, A., Culshaw, M.G. and Bell, F.G. 1995. Regional distribution of sulphate rocks and soils of Britain. 95-104 in Eddleston, M., Walthall, S., Cripps, J.C. and Culshaw, M.G. (eds) Engineering Geology of Construction. Geological Society Engineering Geology Special Publication No10.

Kempton, G.T., Lawson, C.R. Jones. C.J.F.P. \& Demerdash, M. 1996. The use of geosynthetics to prevent the structural collapse of fills over areas prone to subsidence. In De Groot, Den Hoedt and Termaat (eds) Geosynthetics: Applications, Design and Construction. Balkema, Rotterdam.

Poupelloz, B. \& ToulemonT, M. 1981. Stabilisation des terrains karstiques par injection. Le cas du Lutetian gypseux de la region de Paris. Bulletin of the International Association of Engineering Geology. No. 24. 111-123.

Reeves, G.M., Hilary, J. and Screaton, D. 1993. Site investigation techniques for piled foundations in Mercia Mudstones, Teesside, Cleveland County. 457-463 in Cripps, J.C., Coulthard, J.C., Culshaw, M.G., Forster, A., Hencher, S.R. and Moon, C. (eds). The Engineering Geology of Weak Rock. Proceedings of the 26th annual conference of the Engineering Group of the Geological Society, Leeds, September, 1990. A.A..Balkema, Rotterdam.

Reuter, F. and Tolmačëv, V.V. 1990. Bauen und Bergbau in Senkungs und Erdfallgebieten, Eine Ingenieurgeologie des Karstes. Schriftenreihe für Geologische Wissenschaften, Vol 28. Academie-Verlag, Berlin.

Ryder, P F, \& Cooper, A H. 1993. A cave system in Permian gypsum at Houtsay Quarry, Newbiggin, Cumbria, England. Cave Science, Vol. 20, No. 1, 23-28.

Seedhouse, R.L. and Sanders, R.L. 1993. Investigations for cooling tower foundations in Mercia Mudstone at Ratcliffe-on-Soar, Nottinghamshire. 465-471 in Cripps, J.C., Coulthard, J.C., Culshaw, M.G., Forster, A., Hencher, S.R. and Moon, C. (eds). The Engineering Geology of Weak Rock. Proceedings of the 26th annual conference of the Engineering Group of the Geological Society, Leeds, September, 1990. A.A..Balkema, Rotterdam.

Sherlock, R.L. and Hollingworth, S.E. 1938. Gypsum and anhydrite. Special reports on the mineral resources of Great Britain. Vol. 3., 3rd edition. Memoirs of the Geological Survey. 98pp.

Smith, B. 1918. The Chellaston gypsum breccia and its relation to the gypsum-anhydrite deposits of Britain. Quarterly Journal of the Geological Society, London. Vol. 77. 174-203.

Sorochan, E.A., Troitzky, G.M., Tolmachyov, V.V., Khomenko, V.P., Klepikov,S.N., Metelyuk, N.S. and Grigoruk, P.D. 1985. Antikarst protection for buildings and structures. 2457-2460 in Proceedings of the eleventh international conference on soil mechanics and foundation engineering. San Francisco, $12^{\text {th }}-16^{\text {th }}$ August 1995. A.A.Balkema, Rotterdam.

Thomson, A., Hine, P.D., Greig, J.R. and Peach, D.W. 1996. Assessment of subsidence arising from gypsum dissolution: Technical Report for the Department of the Environment. 228pp. Symonds Group Ltd, East Grinstead.

Wynne, T.T. 1906. Gypsum, and its occurrence in the Dove Valley. Transactions of the Institute of Mining Engineers, Vol. 32, 171-192. 